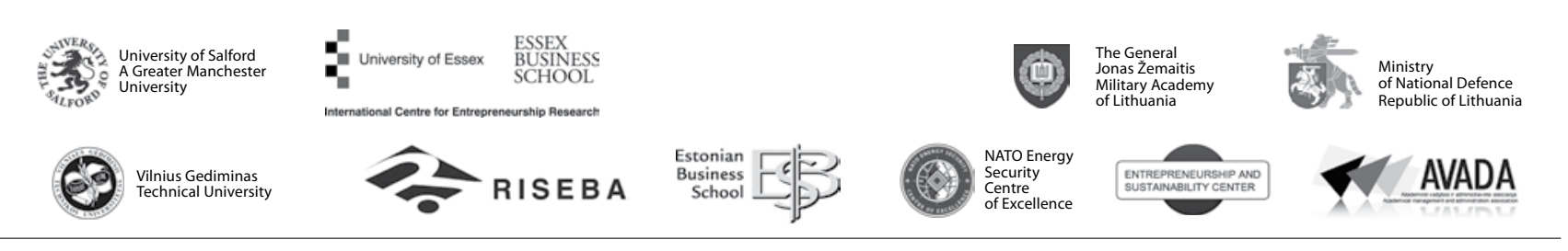

\author{
JOURNAL OF SECURITY AND SUSTAINABILITY ISSUES \\ ISSN 2029-7017 print/ISSN 2029-7025 online \\ 2017 June Volume 6 Number 4 \\ http://doi.org/10.9770/jssi.2017.6.4(13)
}

\title{
TOWARDS SUSTAINABLE ECONOMIC DEVELOPMENT VIA SOCIAL ENTREPRENEURSHIP
}

\author{
Yuriy Bilan', Halyna Mishchuk ${ }^{2}$, Roman Pylypchuk ${ }^{3}$ \\ ${ }^{1}$ Centre of Applied Economic Research, Faculty of Management and Economics, Tomas Bata University in Zlin, \\ 5139 Mostni Str., Zlin, 760 01, Czech Republic \\ ${ }^{2}$ National University of Water and Environmental Engineering, Soborna, 11, Rivne, Ukraine \\ ${ }^{3}$ National University of Water and Environmental Engineering, Soborna str., 11, Rivne, Ukraine \\ E-mails:'1mischuk_galina@ukr.net; 2yuriy_bilan@yahoo.co.uk; 3alfaprodin@gmail.com
}

Received 10 December 2016; accepted 25 March 2017

\begin{abstract}
This paper argues that social enterprises (SE) in EU Member States share at least following common features: the dominance of a social or societal objective over market goal, an apparent social responsibility, particularly in the field of profit distribution. However, numeric limits for the criteria of SE identification remain 'unclear': in the majority of cases there are no comprehensible requirements regarding the employment of vulnerable groups and the reinvestment of profits into social projects. Bulgaria, Croatia, Czech Republic, Finland, Italy, Lithuania, and Slovakia advocate accuracy and precision in dealing with the terminology surrounding $\mathrm{SE}$ regulatory and legal acts to the greatest extent. Being a significant facilitator of sustainable development, SE growth has a close relationship with certain macroeconomic factors. Our correlation and regression analysis clearly proves that there are certain factors of financial and social environment which have the greatest impact on the increase of the number of SE per 10,000 population, namely: Monetary Freedom, Income Distribution and Helping a Stranger. The first two factors show the impact of government regulation quality in business relation, including the links between employers and employees. The latter factor demonstrates an average social perception of so-called 'inclusion ideas' in different societies.
\end{abstract}

Keywords: social entrepreneurship, sustainable development, market factors, government regulation

Reference to this paper should be made as follows: Bilan, Y., Mishchuk, H., Pylypchuk, R. 2017. Towards sustainable economic development via social entrepreneurship, Journal of Security and Sustainability Issues 6(4): 691-702 http://doi.org/10.9770/jssi.2017.6.4(13)

JEL classification: J21, M38.

\section{Introduction}

The concept of social entrepreneurship has emerged as a response to the dominance of tough economic concepts aimed at maximizing profits which remained the main feature of the enterprise efficiency for a long time. As an effective tool to deliver policy objectives in service delivery and social inclusion, social enterprises are not only one of the best and most civilized manifestations of the welfare of sustainable state (Urbaniec, 2015; Sun, et al. 2015; Streimikiene et al., 2016; Samašonok et al. 2016; Boonyachut, 2016; Raudeliūnienė et al., 2016 Dobele et al., 2015; Mroczek-Czetwertyńska \& Czetwertyński, 2013; (Smékalová et al. 2014; Kljucnikov et al. 2016; Stjepanović et al. 2017; Monni et al. 2017; Dobrovolskienè et al. 2017; Tetsman et al. 2017) and social economy (Bartoš et al., 2015; Štimac \& Šimić, 2012). In fact, they perform an important economic mission: they create jobs for individuals who have been passive recipients of state aid or for various reasons have found themselves 〈on the verge〉 of society. This approach does not only ensure the chances of social activity and decent life for individuals, it also allows solving macroeconomic issues of budget support for vulnerable social 
categories as they change from social assistance recipients to active taxpayers through employment and obtaining income from it (Gawel, 2010; O〉Leary, 2015, Sulphey, Alkahtani, 2017; Lace et al. 2015; Tvaronavičiené, 2016; Grinevica et al. 2016; Teletov et al. 2017).

In today's economy despite the social significance of social entrepreneurship its main features remain uncertain and controversial (Bernat et al., 2016). This fact hinders the development of mechanisms of SE state support: if there are no clear criteria for the selection of those companies among other groups, it is impossible to provide them with some economic preferences that will stimulate their further development. Furthermore, other companies which despite receiving the formal status of 'social enterprise' may actually have a dominant market objective can take advantage of these benefits and incentives. In order to find and promote the best European practices of social entrepreneurship we have analysed the definitions and boundaries of formal SE identification in EU Member States. At the same time in order to assess SE economic performance against the factors of social, institutional (Delibasic, 2016; Draskovic et al., 2017) and market environment (Sobeková Majková, et al., 2014; Veljkovic et al., 2015) we have conducted correlation analysis and interaction modelling. The theoretical generalizations and methodological principles for selecting factors that affect the SE development suggested in this in-depth study can be used as the source for improvement of SE legal support and for the application of the most effective state leverage in those countries where such activity has not been formed yet.

\section{Literature Review}

The evaluation of SE performance and operating conditions requires reliable statistical data. This task is complicated due to the lack of recognized methodological principles that would be the basis for the SE allocation among other companies and the introduction of mechanisms of state support for this particular type of business.

As of today, methodology and methodical bases for monitoring the number of social enterprises mainly exist in the form of some conceptual proposals for individual countries. In most cases they are not even enshrined in law however they are commonly used in the society to describe this type of social innovation in the field of employment. Simultaneously, in some countries, mainly in those with high level of development, SE become more common, therefore requiring clarification of their nature and unifying criteria for their identification, at least within the EU. With some differences in SE practices, nowadays most countries more or less use the altered SE conception, which European prototype can be considered a specific legal form for 'social co-operatives' that was legislatively adopted by the Italian parliament in 1991 (Defourny, Nyssens, 2010, p.33).

In its modern sense the term 'social enterprise' was introduced to the European official terminology by the European Commission in 2011 and since then it has been used to cover the following types of business (European Commission, 2011):

- those for which the social or societal objective of the common good is the reason for the commercial activity, often in the form of a high level of social innovation (Kozubíková \& Zoubková, 2016),

- those where profits are mainly reinvested with a view to achieving this social objective,

- and where the method of organisation or ownership system reflects their mission, using democratic or participatory principles or focusing on social justice.

The methodological principles of mapping social enterprises and their eco-systems created by experts of the European Commission as part of a special review of social entrepreneurship in 28 EU Member States and Switzerland (April 2013) can be viewed as the beginning of the current methodology for assessing the SE dynamics and performance. According to the results of this study (European Commission, 2014), a common feature of $\mathrm{SE}$ is the prevalence of micro and small entities with employment below 50 employees and turnover around EUR 1 million. However, further analysis of the characteristics of SE revealed in this study suggests there is a substantial difference in social positions regarding the characteristics that can identify SE, as well as significant differences in their legal forms (Table 1). 
Table 1: Differences in Perception, as well as Organisational and Legal Forms of Social Enterprise across EU

\begin{tabular}{|c|c|c|c|c|}
\hline Country & $\begin{array}{l}\text { SE Concept } \\
\text { is / is not } \\
\text { Legally } \\
\text { Adopted } \\
(+/-)^{*}\end{array}$ & Forms & $\begin{array}{l}\text { Numeric Criteria } \\
\text { for Identifying SE }\end{array}$ & $\begin{array}{l}\text { Organisational and Legal } \\
\text { Forms Commonly Used } \\
\text { by Social Enterprises }\end{array}$ \\
\hline Austria & - & $\begin{array}{l}\text { Work Integration Social En- } \\
\text { terprise (WISE), or more pre- } \\
\text { cisely, SÖBs and GBPs }\end{array}$ & There are no criteria & $\begin{array}{l}\text { Socio-economic enterprises; } \\
\text { NGOs** / Non-profit } \\
\text { employment projects/companies }\end{array}$ \\
\hline Belgium & - & Social purpose company, WISE & There are no criteria & $\begin{array}{l}\text { Enterprises; NGO; NPOs, Foun- } \\
\text { dations serving a public interest }\end{array}$ \\
\hline Bulgaria & + & $\begin{array}{l}\text { Specialised enterprises for } \\
\text { people with disabilities }\end{array}$ & $\begin{array}{l}\text { - They regularly invest more than } \\
50 \text { per cent of the profit in the } \\
\text { achievement of social aims; } \\
\text { - Over } 30 \text { per cent of their staff } \\
\text { comprises vulnerable people. }\end{array}$ & $\begin{array}{l}\text { Cooperatives; Associations, } \\
\text { Enterprises; Foundations; Enter- } \\
\text { prises set up by Non-profit legal } \\
\text { entities (NPLEs) }\end{array}$ \\
\hline Croatia & + & $\begin{array}{l}\text { Civil society organizations } \\
\text { engaged in business, their sub- } \\
\text { sidiaries and cooperatives }\end{array}$ & $\begin{array}{l}\text { - At least } 25 \% \text { of the income is gen- } \\
\text { erated through economic activities; } \\
\text { - At least } 75 \% \text { of the profit or } \\
\text { surplus must be re-invested in the } \\
\text { enterprise's social purpose. }\end{array}$ & NGOs; Social cooperatives \\
\hline Cyprus & - & $\begin{array}{l}\text { volunteer/ NGO organisations, } \\
\text { private companies or coopera- } \\
\text { tives }\end{array}$ & There are no criteria & $\begin{array}{l}\text { Limited Liability Companies; } \\
\text { NGOs (incl. Non-profit compa- } \\
\text { nies, Associations, Foundations, } \\
\text { Clubs) }\end{array}$ \\
\hline $\begin{array}{l}\text { Czech Re- } \\
\text { public }\end{array}$ & $+/-$ & $\begin{array}{l}\text { Social Enterprises satisfying } \\
\text { The Thematic Network of } \\
\text { Social Economy (TESSEA) } \\
\text { definition }\end{array}$ & $\begin{array}{l}\text { - At least } 10 \% \text { ( } 30 \% \text { for WISE) of } \\
\text { total revenues has to come from } \\
\text { sales of goods and services; } \\
\text { - They must reinvest at least } \\
51 \% \text { of profit into development } \\
\text { of the social enterprise and / } \\
\text { or implementation of socially } \\
\text { beneficial aims; } \\
\text { - At least } 30 \% \text { of employees must } \\
\text { be from groups disadvantaged on } \\
\text { the labour market. }\end{array}$ & $\begin{array}{l}\text { Social cooperatives, Civic associ- } \\
\text { ation, Public benefit organisation; } \\
\text { Limited liability companies }\end{array}$ \\
\hline Denmark & + & Enterprises with social purpose & There are no criteria & $\begin{array}{l}\text { Associations; Foundations; Com- } \\
\text { pany limited by shares ("CLS"); } \\
\text { NGOs }\end{array}$ \\
\hline Estonia & $+/-$ & - & $\begin{array}{l}\text { - Entrepreneurial revenue up to } \\
\text { at least } 35 \text { per cent of the total in- } \\
\text { come; } \\
\text { - All profit should be reinvested } \\
\text { into the organisation. }\end{array}$ & $\begin{array}{l}\text { Associations; Foundations; hy- } \\
\text { brid organisations (foundations } \\
\text { association); Limited companies }\end{array}$ \\
\hline Finland & + & $\begin{array}{l}\text { WISE; Businesses owned by } \\
\text { TSOs (clear social mission } \\
\text { statement); Social Enterprise } \\
\text { Mark holders }\end{array}$ & $\begin{array}{l}\text { The enterprise uses over } 50 \text { per } \\
\text { cent of its profits towards meeting } \\
\text { social objectives. }\end{array}$ & $\begin{array}{l}\text { Limited companies, Coopera- } \\
\text { tives, Foundations and Associa- } \\
\text { tions with profits }\end{array}$ \\
\hline France & - & $\begin{array}{l}\text { Enterprise for the reintegration } \\
\text { of economic activity (approxi- } \\
\text { mate to WISE) }\end{array}$ & There are no criteria & $\begin{array}{l}\text { Public utility cooperatives, Non- } \\
\text { profit organisations (associations } \\
\text { and foundations) with com- } \\
\text { mercial activities, Mainstream } \\
\text { enterprises }\end{array}$ \\
\hline Germany & - & Public Benefit Company & There are no criteria & $\begin{array}{l}\text { Limited companies; Associations; } \\
\text { Foundations and Cooperatives; } \\
\text { Enterprises with a social mission; } \\
\text { Welfare organisations }\end{array}$ \\
\hline Greece & - & $\begin{array}{l}\text { Women agro-tourist coopera- } \\
\text { tives; Limited liability social } \\
\text { cooperatives; Social coopera- } \\
\text { tive enterprises }\end{array}$ & There are no criteria & $\begin{array}{l}\text { Civic cooperatives; Rural coop- } \\
\text { eratives; Companies limited by } \\
\text { shares }\end{array}$ \\
\hline Hungary & - & Social cooperatives & There are no criteria & $\begin{array}{l}\text { Cooperatives; Non-profit com- } \\
\text { panies }\end{array}$ \\
\hline Ireland & + & - & There are no criteria & $\begin{array}{l}\text { Company limited by guarantee } \\
\text { (CLG); Company limited by } \\
\text { shares (CLS); Unincorporated } \\
\text { Association }\end{array}$ \\
\hline Italy & + & $\begin{array}{l}\text { - SE type A (cooperatives sup- } \\
\text { plying social, health and } \\
\text { educational services); } \\
\text { - SE type B (which is WISE) }\end{array}$ & $\begin{array}{l}\text { - They generate at least } 70 \text { per cent } \\
\text { of its income from entrepreneurial } \\
\text { activities having social utility }\end{array}$ & $\begin{array}{l}\text { Mainstream enterprises; Coopera- } \\
\text { tives; Foundations; Associations }\end{array}$ \\
\hline
\end{tabular}




\begin{tabular}{|c|c|c|c|c|}
\hline Latvia & $+/-$ & - & There are no criteria & $\begin{array}{l}\text { Private Limited Liability Compa- } \\
\text { nies; Associations or foundations } \\
\text { with a Public Benefit Organisa- } \\
\text { tion (PBO) status } \\
\end{array}$ \\
\hline \multirow[b]{2}{*}{ Lithuania } & \multirow[b]{2}{*}{+} & Social enterprise by Law & $\begin{array}{l}\text { - The employees who are attrib- } \\
\text { uted to the target groups account } \\
\text { for at least } 40 \text { per cent of annual } \\
\text { weighted average number of the } \\
\text { employees on the staff list, and the } \\
\text { number of such employees is not } \\
\text { less than four; }\end{array}$ & \multirow{2}{*}{$\begin{array}{l}\text { Private limited liability com- } \\
\text { panies/ joint stock companies; } \\
\text { Public entities/establishments; } \\
\text { Individual enterprises; NGOs }\end{array}$} \\
\hline & & SE of the disabled & $\begin{array}{l}\text { - The employees who are attributed } \\
\text { to the target group of the disabled } \\
\text { account for not less than } 50 \text { per } \\
\text { cent of the annual average number } \\
\text { of employees on the staff list. Dis- } \\
\text { abled for whom severe or moderate } \\
\text { disability has been established - for } \\
\text { not less than } 40 \text { per cent, and the } \\
\text { number is not less than four. }\end{array}$ & \\
\hline Luxembourg & + & $\begin{array}{l}\text { Organisations that are labelled } \\
\text { as a part of social/ solidarity } \\
\text { economy }\end{array}$ & There are no criteria & $\begin{array}{l}\text { Associations (asbl); Cooperative } \\
\text { companies (cc); Mutuals, } \\
\text { Foundations }\end{array}$ \\
\hline Malta & $+/-$ & - & There are no criteria & $\begin{array}{l}\text { NGOs/voluntary organisations; } \\
\text { Cooperative societies }\end{array}$ \\
\hline Netherlands & - & $\begin{array}{l}\text { Work integration companies; } \\
\text { 'Social' cooperatives }\end{array}$ & There are no criteria & $\begin{array}{l}\text { Associations; Foundations; } \\
\text { Cooperatives; Private limited } \\
\text { liability companies } \\
\end{array}$ \\
\hline Poland & - & $\begin{array}{l}\text { Co-operatives for the disabled } \\
\text { and blind; Social cooperatives; } \\
\text { Professional Activity Establish- } \\
\text { ments (ZAZ); Occupational } \\
\text { Therapy Workshops (WTZ) }\end{array}$ & There are no criteria & $\begin{array}{l}\text { NGOs or Non-profit companies; } \\
\text { Cooperatives; Limited liability } \\
\text { companies; Associations; Foun- } \\
\text { dations }\end{array}$ \\
\hline Portugal & - & $\begin{array}{l}\text { Private institutions of social } \\
\text { solidarity }\end{array}$ & There are no criteria & $\begin{array}{l}\text { Foundations; Mutual Associa- } \\
\text { tions; Cooperatives, incl. Limited } \\
\text { Liability Cooperatives }\end{array}$ \\
\hline Romania & - & $\begin{array}{l}\text { Mutual aid associations for } \\
\text { pensioners; Law protected units } \\
\text { - run by NGOs (Work integra- } \\
\text { tion for disabled people) }\end{array}$ & There are no criteria & $\begin{array}{l}\text { Associations; Foundations; Mu- } \\
\text { tual help associations / credit } \\
\text { unions; and Sheltered workshops } \\
\text { run by NGOs }\end{array}$ \\
\hline Slovakia & + & - & $\begin{array}{l}\text { - At least } 30 \text { per cent of their work- } \\
\text { force must constitute of disadvan- } \\
\text { taged jobseekers; } \\
\text { - They reinvest at least } 30 \text { per cent } \\
\text { of profits into creation of new job } \\
\text { positions or into improving work- } \\
\text { ing conditions. }\end{array}$ & $\begin{array}{l}\text { Non-profit organisations; } \\
\text { Cooperatives; Municipality } \\
\text { companies/local public enter- } \\
\text { prises }\end{array}$ \\
\hline Slovenia & + & $\begin{array}{l}\text { - SE type A (which carries out } \\
\text { (one or several) «social } \\
\text { entrepreneurship activities» } \\
\text { - SE type B (which is WISE) }\end{array}$ & There are no criteria & $\begin{array}{l}\text { Cooperatives; Institutions; } \\
\text { Companies limited by shares }\end{array}$ \\
\hline Spain & - & $\begin{array}{l}\text { Social initiative cooperatives; } \\
\text { WISE; Sheltered Employment } \\
\text { Centres }\end{array}$ & There are no criteria & $\begin{array}{l}\text { Worker-owned companies; non- } \\
\text { profit organisations with commer- } \\
\text { cial activities }\end{array}$ \\
\hline Sweden & - & $\begin{array}{l}\text { WISE; Market-producing civil } \\
\text { society organisations; } \\
\text { Economically active civil } \\
\text { society organisations }\end{array}$ & There are no criteria & $\begin{array}{l}\text { Limited Companies; Non-profit } \\
\text { associations; Economic associa- } \\
\text { tions }\end{array}$ \\
\hline $\begin{array}{l}\text { United } \\
\text { Kingdom }\end{array}$ & + & $\begin{array}{l}\text { Social Firms; Development } \\
\text { Trusts; Intermediate Labour } \\
\text { Market Companies; Commu- } \\
\text { nity Businesses; Credit Unions; } \\
\text { Charities Trading Arms }\end{array}$ & There are no criteria & $\begin{array}{l}\text { Companies limited by guarantee } \\
\text { (CLG); Companies limited by } \\
\text { shares (CLS, less frequently); } \\
\text { Community Interest Companies } \\
\text { (CICs); Industrial and Provident } \\
\text { Societies; Limited Liability } \\
\text { Partnerships }\end{array}$ \\
\hline
\end{tabular}

* (-) No official definition, de-facto their various types are commonly used in the society; (+/-) There are no institutionalised forms of social enterprise, but the concept is commonly used in the society.

** Non-profit organizations, including those conducting economic activity. 
Basing on the above-mentioned practices of SE activity it is absolutely obvious that in their vast majority they are created as a response to the needs of vulnerable target groups. Hence one of the most developed forms of social enterprises in EU is Work Integration Social Enterprise (WISE). WISEs' defining purpose is to help disadvantaged individuals who are at risk of permanent exclusion from the labour market, to integrate into work and society through productive activity, mainly through jobs, professional training and other types of assistance (O'Connor, Meinhard, 2014, p.6). They do this by operating businesses that produce and sell goods and services, and that employ these individuals in the production and sales of these goods and services. WISE is the most common form the social enterprises in Italy, Latvia, Lithuania, Poland, Slovakia, Slovenia, Hungary and the Czech Republic. SE is not only a common practice in these countries as well as in Bulgaria, Croatia and Finland, but their activity is carried out under clearly defined identification criteria enshrined in national legislation. For instance, over 30 per cent of SE staff in these countries comprises vulnerable people and as for the reinvestment of profits for social purposes, reinvesting at least $50 \%$ of profit into socially beneficial aims is the most common practice.

At the same time, one can see a much greater prevalence and clearer formalization of institutional and legal framework of social enterprises in new member states, mostly among post-socialist states. In many other countries, even with much higher economic growth and a greater prevalence of SE forms, this business often has no clear formal boundaries that is largely the result of market self-regulation and significant social capital of the societies. For example, so-called Community Interest Companies' operate in the UK since 2005, and nowadays the principles of their activity have been transferred to most SE forms in EU. They are the most successful example of solution for problems in employment of vulnerable groups in the world, although without a very clear legal definition.

Apart from the presence or absence of clear identification restrictions, there are other inconsistencies on the understanding of the SE features in EU. In particular, in the relevant report (European Commission, 2014) there is a discussion regarding the following aspects: the justification of the companies' division on 'traditional' and 'social' (Finland); balance between market and social objectives (Austria, Czech Republic, Netherlands); allocation of the dominant feature: the organization of the employment of vulnerable groups or volunteer activity (Denmark, Greece); the principle of participation in the company management (Czech Republic).

However, in any case these documents of the European Commission undoubtedly form the basis of modern approaches to SE identification. Their essence is reflected in the following main features, namely: social orientation, i.e. the organisation must pursue an explicit and primary social aim; high social responsibility, especially vector responsibility to society in solving the most complex social issues; willingness to maintain the chosen activity, including through reinvestment of a significant share of the profits.

\section{Methodology and Research Method}

Existing methodological differences in the features highlighting social enterprises in some EU Member States do not allow the scientists to operate totally objective information about their number, moreover their economic performance (profitability, growth and other assets) are not even monitored by EU or other group of countries. Therefore, it is very complicated to form the most favourable data array for statistical analysis due to the abovenoted restrictions. Given this, in our further analysis we would view social enterprises per 10,000 population as a resulting indicator of the SE activity - defined on the basis of survey data (European Commission, 2014) with all the existing national limitations for SE identification.

In order to identify the factors of SE institutional environment which can have the greatest impact on their development, we used Multivariate Data Analysis technique with multistage test to assess connections in intermediate versions and final version of the model basing on VIF (variance inflation factor - hereinafter VIF). We have applied this approach with the use of methodical bases thoroughly set forth in the scientific work on econometrics, for example (Hair et al., 2007; Miles ,, Shevlin, 2001; Montgomery et al., 2015): unlike simple modifications of multivariate regression analysis this technique provides a more accurate result in the process of factor selection and model tests. 
We selected the VIF us as a tool for constructing accurate models due to the fact that its use allows clear elimination of the variables that significantly correlate, moreover it allows to avoid collinearity of independent variables. The VIF can be expressed with the following formula:

$$
V I F=\frac{1}{1-R_{j}^{2}}
$$

where $R_{j}^{2}$ is the coefficient of multiple correlation of the explanatory variable $X_{j}$ with all the other explanatory variables.

If the variables do not correlate, $V I F_{j}$ equals to 1 ; if the correlation is strong, $V I F_{j}$ is more than 10 . In general, $V I F_{j}>5$ is a critical level, indicating the need to partly or completely replace model factors. For higher accuracy of results it is worth using lower threshold values; in our case we believe that $V I F_{j}<3$ shall be a reasonable level in the formation of the final model as it corresponds to the low level of factor collinearity and allows selecting the most important levers of influence on the SE environment.

The selection of factors that may have a significant impact on the external environment of SE has been carried out on the basis of relevant international reports (CAF World Giving Index, 2015; Global Competitiveness Report, 2015-2016; Human Development Report, 2015; Index of Economic Freedom, 2015; Sustainable Society Index, 2014). The comparability of the data time range was provided due to the existing time lag in collecting and publishing information on these macroeconomic indicators. Therefore there are no significant errors in the use of the data from the review of SE activity published in 2014.

The authors have used the following hypotheses in the process of factor selection:

1) initiation of a prospective SE depends on the quality of the environment of financial and infrastructural business support existing in the country in general, including the terms and conditions of intellectual potential management;

2) willingness to establish social business depends on the level of social interaction in society, justice in social processes, and social development.

The study has been conducted on the case study of EU Member States, given its current structure at the time of the research. In order to avoid redundant model testing procedures, the authors have completed a continuous assessment of the resulting indicator (the number of SE per 10,000 population) with each of the factors in these reports at the first stage of factor selection. As a result of calculating the pair correlation coefficients for the factors we have selected only those that had the strength of relationship (correlation ratio) of at least 0.4 and were compatible with the logics that we accepted while constructing hypotheses.

The application of the methods of correlation analysis is hampered to some extent by the existing inconsistencies referring to social enterprises due to the existence of differences in national models of their identification listed in Table 1. Thus, the obtained mathematical results on high (or vice versa) strength of relationship factor may cause doubts due to the use of this particular dataset. However, the use of other methods of economic and mathematical modelling of the relationship between the factors of institutional business support environment and its impact on the activity of establishing social enterprises is very limited at this stage of development of this business, as more reliable statistical data simply do not exist. The use of other methods for collecting information (such as own large-scale social surveys) by individual investigators neither will identify common patterns for the EU Member States, nor allow to use current best practices in other countries.

The fundamental difference between the further analysis of our results and other studies in this field lies in the fact of using the dataset on SE development at the macroeconomic level in relationship with the factors that characterize the quality and conditions of the country development from two different regulatory views: external (state) and self-regulation in society through appropriate changes in consciousness and development objectives. Furthermore, in our study, we use the information on the number of SE, identifying them from the dataset contained in the relevant report (European Commission, 2014), while taking into account the limitations 
typical for each EU member state. By making an allowance for population as a basis of SE number comparison, we can eliminate demographic influences and acquire the most reliable results regarding the effectiveness of the impact of the factors regulating conditions of business activity on the SE development.

\section{Results}

In order to test the constructed hypotheses, the factors which meet the criteria described above with regard to inclusion into the model assessing the impact on SE development have been consolidated into two groups:

1) the factors that allow to assess the environment of financial and infrastructural business support (hypothesis 1):

1.1) Monetary Freedom;

1.2) Foreign Direct Investment Inflow (Millions);

1.3) Quality of Management Schools;

1.4) Country Capacity to Retain Talent;

1.5) State of Cluster Development;

1.6) Extent of Marketing;

1) the factors that characterize the social environment of SE development (hypothesis 2):

1.1) Healthy Life (years);

1.2) Income Distribution (ratio value);

1.3) Buyer Sophistication;

1.4) Volunteered Time (\% answering yes);

1.5) Helping a Stranger (\%).

Numerical values of the factors have been used from the reports or reviews as follows: (CAF, 2015) - factor 2.5; (WEF, 2015-2016) - factors 1.3; 1.4; 1.5; 1.6; 2.3; (UNDP, 2015) - factor 2.4; (IEF, 2015) - factors 1.1; 1.2 ; (SSI, 2014) - factors $2.1 ; 2.2$.

According to the Multivariate Data Analysis technique we have tested relationships with the elimination of the factors that so not correspond to the VIF values: the minimum reference value is VIF $<5.0$; however in order to obtain a more precise assessment results, we accepted $\mathrm{VIF}<3.0$ as the maximum value limit. The factors that corresponded to such margins have been included with relevant $x_{i}$ symbols in the model testing relationships (see Table 2).

Table 2: VIF Results of Assessing Factor Collinearity According to VIF Values

\begin{tabular}{|l|c|c|}
\hline \multicolumn{1}{|c|}{ Dependent Variable (Y) } & VIF & Factors Selected for Modelling \\
\hline Monetary Freedom & 1.186 & $\mathrm{x}_{1}$ \\
\hline Foreign Direct Investment Inflow (Millions) & 1.963 & $\mathrm{x}_{2}$ \\
\hline Healthy Life (years) & 3.106 & - \\
\hline Income Distribution (ratio value) & 1.733 & $\mathrm{x}_{3}$ \\
\hline Quality of Management Schools & 5.356 & - \\
\hline Buyer Sophistication & 6.491 & - \\
\hline Country Capacity to Retain Talent & 9.467 & - \\
\hline State of Cluster Development & 4.418 & - \\
\hline Extent of Marketing & 5.238 & - \\
\hline Volunteered Time (\% answering yes) & 3.053 & - \\
\hline Helping a Stranger (\%) & 2.051 & $\mathrm{x}_{4}$ \\
\hline
\end{tabular}

Source: Own calculations

Since the most important factors have been selected, Table 3 demonstrates their values for understanding of their future use in the models. 
Table 3: Values of the Dependent and Independent Variables Used to Model the Impact of the Macroeconomic Environment on the SE Development

\begin{tabular}{|c|c|c|c|c|c|}
\hline Country & SE per 10,000 population, $y$ & $\mathbf{x}_{1}$ & $\mathbf{x}_{2}$ & $\mathbf{x}_{3}$ & $\mathbf{x}_{4}$ \\
\hline 1 & 2 & 3 & 4 & 5 & 6 \\
\hline Austria & 1.09 & 80.3 & 11082.65 & 7.67 & 55 \\
\hline Belgium & 2.28 & 81.7 & -2405.87 & 9.33 & 54 \\
\hline Bulgaria & 0.60 & 83.2 & 1450.39 & 7.33 & 38 \\
\hline Croatia & 0.50 & 80 & 580.12 & 9 & 43 \\
\hline Cyprus & 0.08 & 82.7 & 533.28 & 6.56 & 58 \\
\hline Czech Republic & 0.53 & 81.2 & 4990.44 & 5.75 & 27 \\
\hline Denmark & 0.52 & 87.6 & 2083.22 & 7 & 53 \\
\hline Estonia & 2.32 & 77.6 & 949.81 & 9.33 & 39 \\
\hline Finland & 4.74 & 79.9 & -1064.85 & 5.75 & 60 \\
\hline France & 4.25 & 77.5 & 4875.46 & 8.33 & 39 \\
\hline Germany & 1.40 & 81.5 & 26720.79 & 7.33 & 61 \\
\hline Greece & 0.63 & 77.8 & 2566.52 & 8.67 & 38 \\
\hline Hungary & 2.12 & 79.2 & 3091.06 & 6.25 & 35 \\
\hline Ireland & 3.46 & 83.9 & 35519.72 & 9 & 59 \\
\hline Italy & 5.95 & 81.2 & 16507.80 & 13.5 & 50 \\
\hline Latvia & 0.07 & 83.8 & 808.35 & 9 & 33 \\
\hline Lithuania & 0.45 & 81.2 & 531.12 & 9.67 & 33 \\
\hline Luxembourg & 4.49 & 80.7 & 30075.37 & 6.2 & 38 \\
\hline Malta & 1.15 & 81.8 & -2099.76 & 6.5 & 50 \\
\hline Netherlands & 3.83 & 79.8 & 24388.87 & 11.5 & 59 \\
\hline Poland & 1.41 & 81.3 & -6037.74 & 8.67 & 51 \\
\hline Portugal & 4.90 & 82.8 & 3114.02 & 15 & 51 \\
\hline Romania & 3.62 & 77.3 & 3616.77 & 5.25 & 54 \\
\hline Slovakia & 1.64 & 75.5 & 590.97 & 5.5 & 32 \\
\hline Slovenia & 4.39 & 81.3 & -678.58 & 8.33 & 50 \\
\hline Spain & 4.70 & 81.3 & 39166.60 & 9 & 54 \\
\hline Sweden & 3.60 & 85.5 & 8149.52 & 5.5 & 55 \\
\hline United Kingdom & 12.52 & 74.4 & 37100.90 & 14 & 63 \\
\hline
\end{tabular}

Source: column 2 - own calculations based on (European Commission, 2014); the sources for columns 3 - 6 were previously given.

Basing on these data we have constructed the following models: four-factor and three-factor ones with all possible factor combinations. The three-factor model appeared to be the most statistically significant one and had the following relationship:

$$
y=f\left(x_{1}, x_{3}, x_{4}\right)
$$

Its full equation looks as follows:

$$
y=25,9623-0,3893 x_{1}+0,38475 x_{3}+0,10543 x_{4}
$$

The model is statistically significant and adequately explains the impact of the factors upon the changes in the number of SE, which can be confirmed by given test results (see Table 4).

Table 4: Results of Model Testing

\begin{tabular}{|l|l|l|c|}
\hline \multicolumn{1}{|c|}{ Indicator } & Value & \multicolumn{1}{|c|}{ Indicator } & Value \\
\hline Multiple correlation coefficient & 0.747 & F-statistics: & 3.39 \\
\hline Coefficient of determination & 0.558 & critical value & 10.08 \\
\hline F-significance of model $(<0.05)$ & 0.0002 & calculated value & \\
\hline P-significance of factors (<0.05): & & t-statistics: & 2.064 \\
\hline Y-intercept & 0.02 & table value & -3.066 \\
\hline $\mathrm{x}_{1}$ & 0.01 & & 2.676 \\
\hline $\mathrm{x}_{3}$ & 0.01 & & $\mathrm{x}_{1}$ \\
\hline $\mathrm{x}_{4}$ & 0.01 & $\mathrm{x}_{3}$ & 2.969 \\
\hline
\end{tabular}


Fairly small numeric values of the indicators that describe the direction and force of the impact of each particular factor can be explained by the high sensitivity of each percentage point to the change of factors included in the model: even minor impacts which should result in minimal changes of the numerical factor values require major economic and social changes in the behaviour of society (all three factors) or changes in regulatory policy (considering Monetary Freedom and Income Distribution).

Therefore, among the chosen factors the higher impact of the social environment of social stakeholder interaction on the SE development is absolutely obvious. As we can see from the model the standards of income distribution adopted in the society can not be exclusively subject to state regulation, however they also to the large extent depend on the public will and awareness. Particularly, the Income Distribution factor characterizes social stability through the equality of the distribution of income of the richest $10 \%$ to the poorest $10 \%$ of the people in a country, while Helping a Stranger is a comprehensive indicator of the 'giving behaviour' in aspects of charity, volunteering, readiness to help for vulnerable people. The impact of these factors is logical because it is based on the fundamental idea of social enterprise: such business arises and develops in the places where society does not accept excessive inequalities in income distribution and where there is a high share of people willing to help in various forms: from charity to active own participation in social business projects.

With regard to Monetary Freedom, the impact of this factor has appeared to be unexpected to some extent. It is known that Monetary Freedom combines a measure of price stability with an assessment of price controls. Apparently, in the given group of countries the average inflation rate for the most recent three years (the first monetary freedom component) hasn't had a significant influence upon the score for the monetary freedom. Thus, the values of this factor have mostly differed is in the 'Price controls' component. As one can see from the model, social enterprises mainly develop in the environments where government control over prices is significant due to the fact that, despite it contradicts economic logic of market regulation to some extent, it can get some benefits for the companies with weaker competitive position at the moment of their creation and at the beginning of their business activity. Social enterprises are basically such companies, and at least for today basing on the case study of the EU Member States we can state that the activeness of their development is directly determined by the timely state regulation of the Monetary Freedom aspects.

\section{Conclusions}

SE development is the result of the evolution of the social responsibility concept which mostly appears through individual initiatives through systemic actions of the state for their support and distribution. In most EU countries the activity of such companies is governed by the standard terms and conditions of business regulation without legal account of their specific features. It is obvious that in the developed European countries this practice is possible and has not required significant government intervention yet, since the initiative to establish SE constantly grows, and business conditions are satisfactory enough for SE organizations in all their diversity and do not require substantial government support. On the other hand, in countries with a lower level of economic development where looking for resources in order to start a business and administrative obstacles along the way are significant, SE identification with the introduction of strict numerical limits for the relevant criteria is an objective necessity. In this way it will be possible to find the companies important for the public, those that address burning social problems, instead of ensuring the existence of 'elevators' driving deceitful or corrupt companies toward different types of government incentives, as those dishonest organisations only use 'social features' as a way of achieving their market goals. In this regard, we believe that the most suitable option for the countries in which the activity of SE is still underdeveloped, however where there is public demand for its activation, should be the use of the practice of the states in which criteria for identifying SE has already proven their effectiveness, i.e.: over 30 per cent of their staff comprises vulnerable people, and there is reinvestment of at least 50 per cent of profit into socially beneficial aims.

After analysing the impact of environment factors on the activeness of SE establishment and development, we have confirmed the high importance of social factors verified by reasonable differentiation of income distribution ('Income Distribution'), as well as overall high level of tolerance and acceptance of social issues in the 
society verified by 'Helping a Stranger' factor. As for the environment of financial and institutional business support, the impact of the 'Monetary Freedom' factor appeared to be the most significant one given the provided data.

It is obvious that our study does not claim to fully and completely satisfy the questions regarding the possibilities of regulation of business activity in establishing SE. We also do understand the uncertainties with reference to the accuracy of the results that may occur because of the existing limitations in the data management on the spread of the SE and existing differences in national approaches to SE identification. Those attributes do create some uncertainty in the formation of the final dataset and there we have described those doubts in this study. However, we suggest a new approach to the analysis of the institutional environment of the interaction in society, which can result in testing all new models that are more relevant to the appropriate hierarchy level or time range, which will take into account other factors affecting SE. The main idea of our study was the creation of methodical bases to assess the impact of the complex of regulatory mechanisms initiated by state and their perception, as well as the standards of conduct determined in the society upon the formation of new and undeniably important element of modern business: the business that exists on traditional commercial basis, that does not depend only on the participation of benefactors, furthermore that is itself the highest expression of new social benefit - the involvement of individuals that used to be vulnerable or even isolated from public life in active social life in terms of employment and income.

\section{References}

Bartoš, P., Rahman, A., Horák, J., Jáčová, H. (2015), Education and Entrepreneurship in the SME Segment in Economic Transformation, Economics \& Sociology 8 (2): 227-239. http://doi.org/10.14254/2071-789X.2015/8-2/16

Bernat T., Maciejewska-Skrendo A., Sawczuk M. (2016), Entrepreneurship - Risk - Genes, experimental study. Part 1 - entrepreneurship and risk relation, Journal of International Studies 9(3): 270-278. http://doi.org/10.14254/2071-8330.2016/9-3/21

Boonyachut, S. (2016). Sustainability of community's entrepreneurship: case of floating market at Ladmayom, Entrepreneurship and Sustainability Issues 4(2): 211-219. http://dx.doi.org/10.9770/jesi.2016.4.2(8)

CAF (2015). CAF World Giving Index. Report. - [Electronic Resource]. - Available at: https://www.cafonline.org/about-us/ publications/2015-publications/world-giving-index-2015

Defourny J., \& Nyssens M. (2010). Conceptions of Social Enterprise and Social Entrepreneurship in Europe and the United States: Convergences and Divergences. Journal of Social Entrepreneurship 1(1): 32-53.

Delibasic, M. (2016), Hypothetical Matrix for Institutional Modeling of the Basis for Economic Development in the Countries of Southeast Europe, Montenegrin Journal of Economics 12(2): 147-159.

Dobele, L.; Grinberga-Zalite, G.; Kelle, L. (2015). Sustainable economic development: scenarios for promotion of social innovation in Latvia, Journal of Security and Sustainability Issues 5(2): 149-158. http://dx.doi.org/10.9770/jssi.2015.5.2(2)

Dobrovolskienė, N.; Tvaronavičienė, M.; Tamošiūnienė, R. (2017). Tackling projects on sustainability: a Lithuanian case study, Entrepreneurship and Sustainability Issues 4(4): 477-488. http://doi.org/10.9770/jesi.2017.4.4(6)

Draskovic, V., Popov, E., Peleckis, K. K. (2017), Modelling of Institutional Changes in Transition Countries - the Gap Between the Theory and Practice, Montenegrin Journal of Economics, Vol. 13, No. 1, pp. 121-140

European Commission (2011). Communication from the Commission to the European Parliament, the Council, the European Economic and Social Committee and the Committee of the Regions. Social Business Initiative Creating a favourable climate for social enterprises, key stakeholders in the social economy and innovation. - [Electronic Resource]. - Available at: http://eur-lex.europa.eu/legal-content/ EN/TXT/?uri=CELEX\%3A52011DC0682

European Commission (2014). A map of social enterprises and their eco-systems in Europe. Synthesis Report. - [Electronic Resource]. Available at: http://ec.europa.eu/social/BlobServlet?docId=12987\&langId=en

Gawel, A. (2010), The Relationship between Entrepreneurship and Unemployment in the Business Cycle, Journal of International Studies, Vol. 3, No 1, 2010, pp. 59-69.

Grinevica, L.; Rivza, B.; Rivza, P. (2016). Scenarios for reducing youth unemployment and promoting sustainability in the regions of 
Latvia, Journal of Security and Sustainability Issues 5(3): 437-449. http://dx.doi.org/10.9770/jssi.2016.5.3(11)

Hair, J., Black, W., Babin, B., Anderson, R., \& Tatham, R. (2007). Multivariate Data Analysis . New Gersey: Pearson Education.

IEF (2015). Index of Economic Freedom- [Electronic Resource]. - Available at: http://www.heritage.org/index/pdf/2015/book/ index_2015.pdf

Kljucnikov, A., Belás, J., Kozubíková, L., \& Paseková, P. (2016). The Entreprenurial Perception of SME Business Environment Quality in the Czech Republic. Journal of Competitiveness, 8(1).

Kozubíková L., Zoubková A. (2016), Entrepreneur's attitude towards innovativeness and competitive aggressiveness: the case study of Czech micro-enterprises, Journal of International Studies 9(1): 192-204. http://doi.org/10.14254/2071-8330.2016/9-1/14

Lace, N.; Buldakova, N.; Rumbinaitè, G. (2015). Organizational creativity as a driving force for company's innovative development, Entrepreneurship and Sustainability Issues 3(2): 137-148. http://dx.doi.org/10.9770/jesi.2015.3.2(2)

Miles, J., \& Shevlin, M. (2001). Applying regression and correlation: A guide for students and researchers. Sage.

Monni, S.; Novelli, G.; Pera, L.; Realini, A. (2017). Workers' buyout: the Italian experience, 1986-2016, Entrepreneurship and Sustainability Issues 4(4): 526-539. http://doi.org/10.9770/jesi.2017.4.4(10)

Montgomery, D. C. Peck, E. A., \& Vining, G. G. (2015). Introduction to linear regression analysis. John Wiley \& Sons.

Mroczek-Czetwertyńska, A., \& Czetwertyński, S. (2013). Przyczyny rozwoju spółdzielczości socjalnej na Dolnym Śląsku w latach 2006-2012 (Reasons for the development of social co-operatives in Lower Silesia in the years 2006-2012), Nauki Spoleczne, 2 (8): 7-18.

O’Connor P., \& Meinhard A. (2014). Work Integration Social Enterprises (WISEs): Their Potential Contribution to Labour Market. - [Electronic Resource]. - Available at: http://www.sess.ca/english/wp-content/uploads/2014/12/OConnorMeinhard.OHCRIF-report-2014.FINAL_.pdf

O'Leary, S. (2015). The Role of Enterprise and Entrepreneurship within Higher Education and Effective Economic Governance Across Central and Eastern Europe, Economics and Sociology 8(2): 143-153. http://doi.org/10.14254/2071-789X.2015/8-2/11

Raudeliūnienė, J.; Stadnik, B.; Kindarytè, R. (2016). Knowledge appliance process: theoretical and practical evaluation aspects, Entrepreneurship and Sustainability Issues 3(4): 368-379. http://dx.doi.org/10.9770/jesi.2016.3.4(5)

Samašonok, K.; Išoraitė, M.; Leškienè-Hussey, B. (2016). The internet entrepreneurship: opportunities and problems, Entrepreneurship and Sustainability Issues 3(4): 329-349. http://dx.doi.org/10.9770/jesi.2016.3.4(3)

Smékalová, L., Hájek, O., Belás, J., \& Machácek, J. (2014). Perception of Small and Medium Entrepreneurship in the Czech Republic. Journal of Competitiveness, 6(4).

Sobeková Majková, M., Solík, J., Sipko, J. (2014), The Analysis of Chosen Business Obstacles and Problems with the Financing of Young Entrepreneurs in Slovakia, Economics and Sociology 7(3): 90-103. http://doi.org/10.14254/2071-789X.2014/7-3/7

SSI (2014). Sustainable Society Index. - [Electronic Resource]. - Available at: http://www.ssfindex.com/

Štimac, H., Šimić, M. L. (2012), Competitiveness in Higher Education: a Need for Marketing Orientation and Service Quality, Economics and Sociology 5(2): 23-34.

Stjepanović, S.; Tomić, D.; Škare, M. (2017). A new approach to measuring green GDP: a cross-country analysis, Entrepreneurship and Sustainability Issues 4(4): 574-590. http://dx.doi.org/10.9770/jesi.2017.4.4(13)

Streimikiene, D., Navikaite, A., Varanavicius, V. (2016) Company's Value Creation Via Customer Satisfaction and Environmental Sustainability Influence, Montenegrin Journal of Economics 12(4): 19-28.

Sulphey, M. M.; Alkahtani, N. S. (2017). Economic security and sustainability through social entrepreneurship: the current Saudi scenario, Journal of Security and Sustainability Issues 6(3): 479-490. http://dx.doi.org/10.9770/jssi.2017.6.3(12)

Sun, L.; Fuschi, D. L. (2015). Sustainable social entrepreneurship and motivation: a case study of two non-profit organisations in the UK, Entrepreneurship and Sustainability Issues 2(4): 179-187. http://dx.doi.org/10.9770/jesi.2015.2.4(1)

Teletov, A.; Nagornyi, Y.; Letunovska, N.; Shevliuga, O. (2017). Competitive and sustainable technological development: focus on business enterprises, Journal of Security and Sustainability Issues 6(3): 491-500. http://dx.doi.org/10.9770/jssi.2017.6.3(13) 
Tetsman, I.; Bazienè, K.; Viselga, G. (2017). Technologies for sustainable circular business: using crushing device for used tires, Entrepreneurship and Sustainability Issues 4(4): 432-440. http://doi.org/10.9770/jesi.2017.4.4(3)

Tvaronavičienè, M. (2016). Start-ups across the EU: if particular tendencies could be trace, Entrepreneurship and Sustainability Issues 3(3): 290-298. http://dx.doi.org/10.9770/jesi.2016.3.3(6)

UNDP (2015). Human Development Report. - [Electronic Resource]. - Available at: http://hdr.undp.org/sites/default/files/2015_human_development_report.pdf

Urbaniec, M. (2015), Towards Sustainable Development through Ecoinnovations: Drivers and Barriers in Poland, Economics and Sociology, Vol. 8, No 4, pp. 179-190. http://doi.org/10.14254/2071-789X.2015/8-4/13

Veljkovic, S., Bogetic, Z., Stojkovic, D. (2015), Using Marketing Approach to Respond to Internationalization Challenges and Changes in Marketing Channels, Montenegrin Journal of Economics 11(2): 79-100.

WEF (2015-2016). Global Competitiveness Report. - [Electronic Resource]. - Available at: http://www3.weforum.org/docs/gcr/20152016/Global_Competitiveness_Report_2015-2016.pdf 